A primeira vez que as fotografias sobre rituais afro-brasileiros de José Medeiros estiveram ao meu olhar corria o ano de 1984, quando me foi apresentado o livro Candomblé, publicado em 1957 pela Editora O Cruzeiro. Elementos inatingíveis pelo olhar leigo, espaços e temporalidades da liminaridade, detalhes do sagrado, impenetráveis ao olhar de um nãoiniciado, eram explicitados pela fotografia e mostrava imagens nunca antes vistas, em recortes detalhistas de todo conjunto de cerimônias que envolvem os ritos de iniciação no candomblé.

Nessa situação, ainda um neófito na área chamada Antropologia Visual, que começava a encontrar seus primeiros caminhos no Brasil como área do

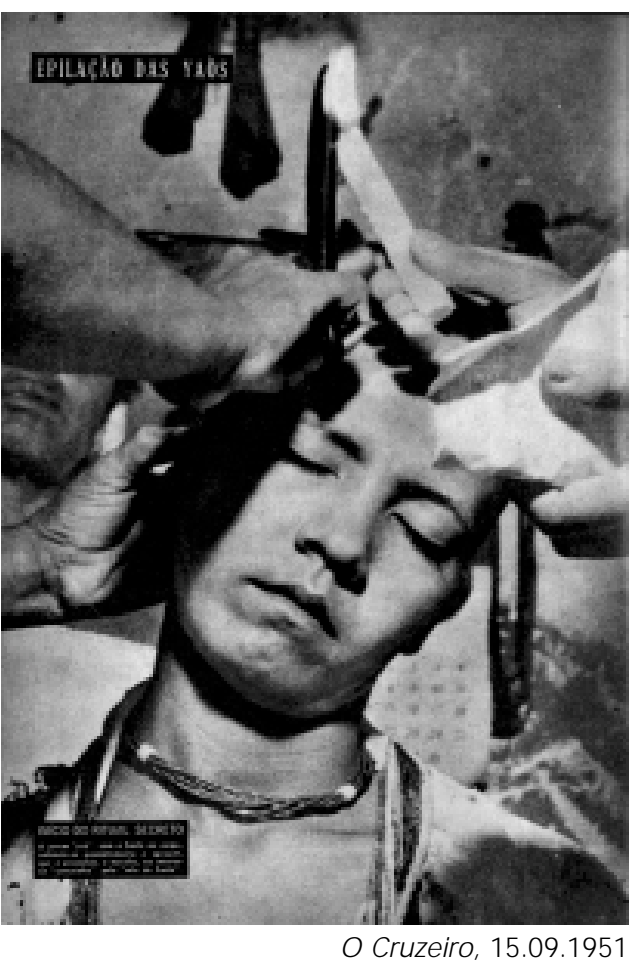
conhecimento, pude ver essas imagens pela primeira vez. As imagens de J osé Medeiros imediatamente saltaram aos meus olhos iniciantes na compreensão da relação entre Antropologia e Imagem, imagens nunca vistas por mim e com certeza Campos 3:147-164, 2003. por muitos pesquisadores nas áreas da Antropologia e da Fotografia, e, como 


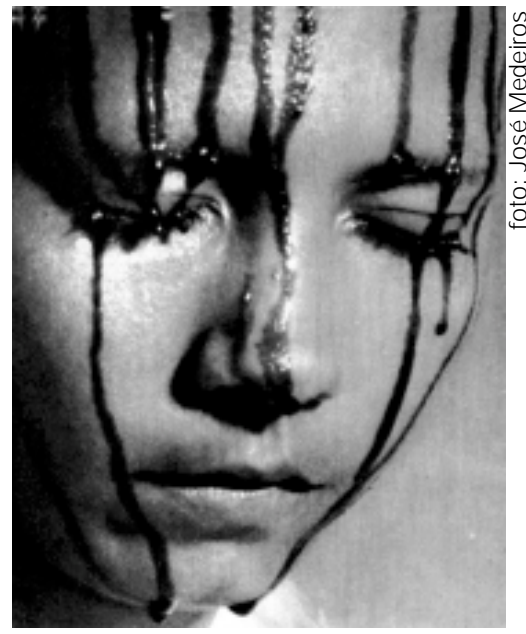

Livro Candomblé, 1957 fotógrafo, percebi que as imagens denotavam estar diante de um fotógrafo especial, com aguçado senso estético para as condições dadas de um ritual e suas dificuldades de documentação.

Percebi que estava perante uma documentação autêntica e original. J á conhecia a importância da fotografia de J osé Medeiros, mas sua obra era inacessível, somente algumas imagens suas tinham sido publicadas até então, fora as publicações da revista O Cruzeiro, também de difícil acesso. O que me atraiu de imediato no conjunto de 60 fotografias foi o olhar inserido na complexidade do ritual e a forma como o fotógrafo realizou as imagens, com proximidade e consentimento. A objetividade no enquadramento com contextualização dos momentos importantes do ritual condensa, principalmente, os detalhes sobre o corpo como suporte ritualístico. Desde o primeiro instante que meu olhar percorreu o conjunto das imagens, identifiquei-as como uma documentação original e de forte valor etnográfico. O texto jornalístico que acompanha as imagens não compromete pelo seu caráter meramente descritivo, com detalhamento para ações, cantos, nomeação de objetos, e uma certa dramaticidade narrativa do evento. O texto e as legendas não identificam o local e as pessoas fotografadas, somente havia a indicação da cidade de Salvador, Bahia. Pensei tratar-se de uma forma de preservação das pessoas que se deixaram fotografar, mas ingenuamente fui percebendo, conforme a pesquisa foi desenvolvendo-se, que tenha sido talvez um caso de simples omissão.

Instigado então pelas imagens que ficariam retidas na minha memória, encontrei-me com o fotógrafo J osé Medeiros em seu apartamento no Rio de J aneiro, em 1988. J osé Medeiros concedeu-me, na ocasião, uma entrevista na qual relatou os fatos aqui apresentados. Eu tinha interesse específico em saber a motivação da reportagem, sua inserção no meio religioso, as relações que propiciaram a feitura das imagens, as conseqüências da publicação e outras informações que ele tivesse sobre o assunto. J osé Medeiros, amável e simpático, foi solícito e conversamos por duas horas. Na conversa indicou-me caminhos importantes com informações que somente ele podia me fornecer naquele momento. Disse ele que em 1951, sentido-se importunado e incomodado por imagens sobre candomblé publicadas por um estrangeiro, resolveu fazer uma reportagem mostrando os aspectos inacessíveis ao olhar leigo dos rituais de iniciação dessa religião afro-brasileira. Segundo ele, a reportagem estrangeira não mostrava o "verdadeiro candomblé". Como era costume no processo de decisão de pauta em O Cruzeiro, os fotógrafos tinham autonomia para propor e conduzir uma reportagem. O enfrentamento com revistas estrangeiras 
era um ponto importante de afirmação para a revista como produto de um jornalismo autêntico e nacional, o caso Flávio publicado na revista Life é um deles.

J unto com o jornalista Arlindo Silva, partiu ele para a Bahia, para tentar uma documentação original dos rituais secretos do candomblé. A dificuldade de aproximação nos terreiros tradicionais levou-os a procurar alternativas e um guia indicou-lhes uma casa não tradicional na qual três iaôs ${ }^{3}$ estavam em reclusão e em processo de iniciação.

Medeiros relatou-nos que teve uma experiência desagradável quando freqüentava os terreiros tradicionais tentando as primeiras aproximações com o intuito de fotografar, e logo em um deles, e mesmo sem portar o equipamento fotográfico, foi questionado por uma mãe-de-santo em transe que se dirigiu diretamente a ele e falou: Você veio aqui para fotografar mas não vai, não!. Medeiros contou-nos essa passagem com um ar de espanto místico, mas, como um fotojornalista exemplar, refletiu internamente que não iria desistir de mostrar o verdadeiro Candomblé e voltar para a redação sem o material prometido. Assim, mesmo fora dos terreiros tradicionais já se sabia de seus objetivos. Afinal, a chegada de um fotógrafo e de um jornalista da revista $\mathrm{O}$ Cruzeiro era assunto em qualquer cidade na época. No depoimento mais informativo de sua vida, Medeiros fala sobre sua sensação de ser um fotógrafo da revista O Cruzeiro: Um fotógrafo da revista era tão famoso quanto é hoje um galã da Globo, cheguei a dar autógrafos na rua. O pessoal ficava vidrado pelo fato do cara ser de $\mathrm{O}$ Cruzeiro. ${ }^{4}$

Assim, ele encontrou um guia que o conduziu a um terreiro na periferia, no qual estariam sendo iniciadas as três iaôs: o Terreiro de Oxóssi, da mãe-de-santo Mãe Riso da Plataforma. Na conversa com Medeiros pela primeira vez ouvi o nome da mãe-de-santo que se deixou fotografar, um dado importante para a pesquisa de campo realizada em 2002, pois pude ir diretamente ao local, o bairro da Plataforma, em Salvador, e encontrar as memórias vivas dos acontecimentos nas pessoas que tiveram alguma relação com o evento ou que foram fotografadas por Medeiros. Somente no final da pesquisa, por meio de conversas com Arlindo Silva, tivemos a informação de como chegaram até o terreiro de Mãe Riso. $O$ também fotógrafo Gervásio Batista apresentou-os a um motorista de táxi, chamado de "Sessenta", que era freqüentador da casa de Riso e sabia da reclusão de três iaôs. Por intermédio de "Sessenta" chegaram até o bairro da llha Amarela, onde ficava o terreiro. Localizado no subúrbio ferroviário, o local era ainda zona rural, com poucas casas e um trajeto muito longo e difícil, passando pela Ribeira e pela Plataforma, muito distante do centro de Salvador.

Contou-nos Medeiros que "pagou" a mãe-de-santo para fotografar as três

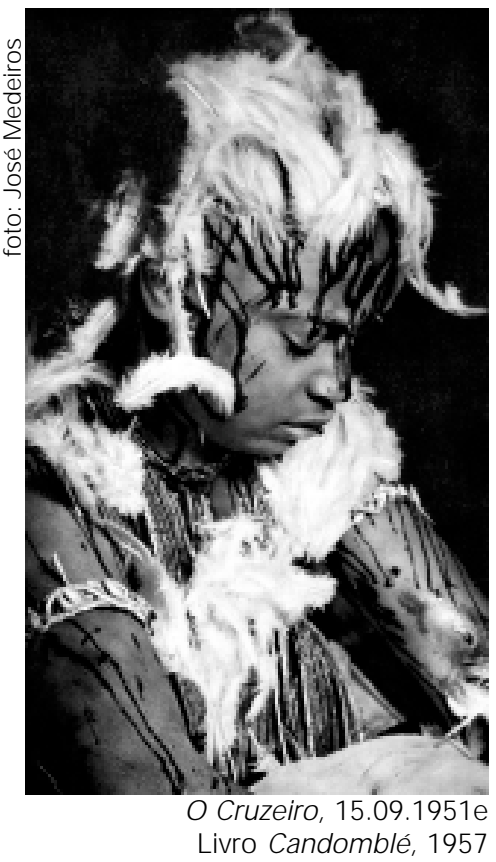


Fernando de Tacca

iaôs dentro de sua reclusão, as etapas do ritual de iniciação e a festa de saída. Na verdade, o "pagamento" referiase aos bichos e outros ingredientes necessários para o ritual. Com a carga mística envolvendo sua fala e o fato de estar documentando procedimentos ritualísticos não veiculados pela mídia brasileira até então, falou-nos com forte ar de mistério que ainda teve problemas com seu equipamento, pois o cabo de sincronismo do flash rompeuse. Como o ambiente era muito escuro, fez as fotos com sua Rolleiflex usando B no anel do obturador ${ }^{5}$. Assim, acionando e segurando o disparador na posição $B$, disparou a luz do flash e imprimiu imagens com ótima qualidade tonal no material fotossensível demonstrando sua capacidade técnica de trabalhar em condições adversas.

\section{O CRUZEIRO}

A reportagem resultante foi publicada no dia 15 de novembro de 1951 na revista O Cruzeiro com o título As Noivas dos Deuses Sanguinários, contendo 38 fotografias. Algumas dessas fotografias de Medeiros, poucas e raras, foram publicadas depois da reportagem e do livro. Elas foram citadas em catálogos e artigos nos anos subseqüentes com erros de datas e falsas informações, mas sempre de uma forma ufanista sobre a importância desse material fotográfico na história do jornalismo brasileiro. Tais citações faziam-se de modo superficial, pois nunca foram acompanhadas de uma análise mais profunda, nem ao menos discutiu-se o próprio campo ético do jornalismo, propício nesse caso. Accioly Neto diretor de redação da revista por mais de 40 anos, deixou uma série de escritos memorialistas dos fatos, dos personagens e dos profissionais com quem conviveu e que seu filho fez publicar no livro O Império do Papel - Os Bastidores de $\mathrm{O}$ Cruzeiro. Accioly Neto, mesmo estando próximo de J osé Medeiros, cometeu o erro grave de localizar as fotos publicadas no tradicional terreiro do Gantois e acentua as dificuldades da reportagem, aumentando assim a mística em torno dela, diz ele:

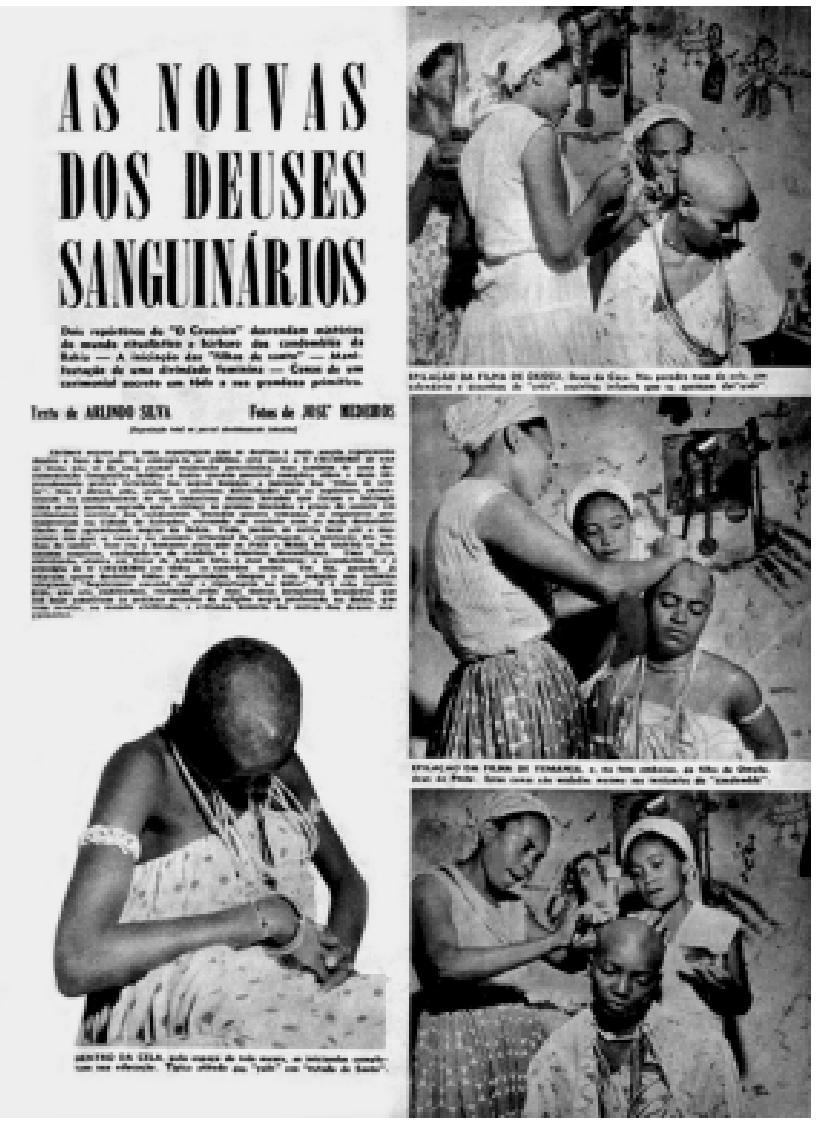

O Cruzeiro, 15.11.1951 
"A atração pelo mistério levou J osé Medeiros também aos terreiros de candomblé em Salvador, Bahia, muitas vezes arriscando-se na tentativa de tirar fotos, que na época eram proibidas. Certa vez conseguiu documentar um ritual de iniciação das filhas-de-santo no terreiro do Gantois, com fotos impressionantes das mulheres de cabeça raspada e marcadas de sangue, que foram publicadas com grande sucesso em O Cruzeiro" (Accioly Neto 1998:120, grifo nosso).

No catálogo da exposição “J osé Medeiros”, Instituto Itaú Cultural, 1997, com curadoria de Rubens Fernandes J únior, uma das fotos reiteradas vezes publicada depois da reportagem em O Cruzeiro em 1951, aparece com a seguinte legenda Candomblé - Iniciação de filha-de-santo, Salvador,1957. A confusão com datas nesse caso devese às duas publicações: da reportagem e do livro. Esse mesmo erro aparece na edição comemorativa dos cinqüenta anos da Editora Abril, em 2000; com o livro A Revista no Brasil, com a publicação de umas das fotos com os seguintes dizeres: ... O Cruzeiro - revista que outro mestre, J osé Medeiros, publicou em 1957 um notável ensaio sobre o candomblé na Bahia. Parece que todos insistem em datar as imagens pela data da edição do livro e não pela data original da reportagem. Mesmo a mais cuidadosa publicação sobre Medeiros, com um depoimento elucidador de sua trajetória, J osé Medeiros - 50 Anos de Fotografia, que acompanhava uma exposição retrospectiva na Funarte/RJ , em 1987, insiste na data de 1957. Nadja Peregrino, que fez a curadoria dessa exposição e do catálogo, juntamente com Ângela Magalhães, publica alguns anos depois, em 1991, o livro o Cruzeiro - A Revolução da Fotorreportagem, no qual analisa, agora diretamente na fonte, a reportagem As Noivas dos Deuses Sanguinários, creditando a data correta das fotografias e publicando uma reprodução de uma página da revista. Sua análise é formal e prende-se somente ao aspecto da diagramação, não abordando o conteúdo da reportagem ou a análise das imagens. Não se sabe quem são as pessoas fotografadas, como a reportagem foi feita, como Medeiros conseguiu fazer as imagens, ou suas motivações. Reforça-se aqui a falta de informações sobre o conjunto de imagens publicados no livro e na revista, de uma pessoa que também esteve muito próxima de Medeiros. A mim, que perseguia essa história, parecia que nunca chegaria a entrar no mundo mágico e religioso fotografado por Medeiros; as imagens e a própria reportagem tangia-se de uma aura intransponível.

Os remissivos erros em questões banais de datas facilmente pesquisáveis são acompanhados por falsas informações, como a de Accioly Neto, e são parte de um grande equívoco em relação à publicação da reportagem e do livro, do qual são cúmplices o mundo jornalístico, próximo e distante de osé Medeiros, e que nunca estabeleceu uma relação analítica com a reportagem para discutir as conseqüências éticas de invasão do universo religioso, como também o meio religioso dos cultos afro-brasileiros que fomentou uma série de versões sobre o caso. Esse grande equívoco dura mais de cinqüentas anos!

Luis Maklouf Carvalho, no seu livro Cobras Criadas - David Nasse e O Cruzeiro, traz um extenso volume de 
Fernando de Tacca

informações sobre a revista e dedica apenas um parágrafo sobre a reportagem e nos relata de maneira mais próxima dos acontecimentos a reportagem de J osé Medeiros e Arlindo Silva:

“... uma impressionante reportagem sobre a iniciação ritualística das filhas-de-santo em um terreiro da Bahia - “ As Noivas dos Deuses Sanguinários" - de 19 de setembro de 1951. Medeiros fotografou a raspagem da cabeça das iaôs e o batismo com o sangue dos animais - fotos depois reproduzidas no livro Candomblé. Arlindo conta que a mãe-de-santo foi perseguida por ter permitido o acesso dos repórteres ao ritual secreto" (Carvalho 2001:236).

Pela primeira vez aparece nos escritos sobre a reportagem, mesmo que somente como um dado e cinqüenta anos depois da publicação da reportagem, um relato sobre as conseqüências impostas à Mãe Riso da Plataforma, que nunca teve seu nome mencionado nas publicações. Para todos, esse anonimato imposto por J osé Medeiros e por Arlindo Silva nunca foi interesse de investigação, nem tampouco todas as decorrências da publicação. Maklouf somente erra na data da revista, compreensível para o volume de dados de seu trabalho e que não compromete as informações precisas sobre a reportagem, mas novamente a importância sobre a reportagem passa despercebida.

No meio antropológico, o acontecimento único de uma reportagem dessa importância ter acontecido, e naquele momento, simplesmente foi ignorada e desprezada como uma possibilidade de estudar as relações da fotografia com o mundo religioso. Segundo Medeiros, a publicação das imagens que mostravam cenas de sacrifício de animais, cenas internas da reclusão e detalhes do processo ritualístico causou muita polêmica no meio do Candomblé na Bahia. Ainda segundo ele, devido à reportagem as iaôs não tiveram sua iniciação reconhecida e assim ficaram marginalizadas dentro da religião, com conseqüências graves para elas. Essas informações ele obteve, quando esteve outras vezes em Salvador, de pessoas com as quais ele encontrava e que tinham relações com o mundo religioso. Medeiros hospedava-se com nome falso para que não fosse identificado como o fotógrafo que fez as fotografias da Cruzeiro, disse-me que tinha medo de ebó. Segundo ele, a mãe-de-santo teria também sofrido muitas perseguições dentro do meio religioso e até mesmo tendo de explicar suas razões de deixar-se fotografar em um delegacia de polícia.

\section{O IMPACTO EM SALVADOR}

Uma série de publicações nos jornais antecedeu a chegada da revista em Salvador e produziu um impacto muito maior do que imaginávamos no começo da pesquisa. O jornal A Tarde, de Salvador, fez publicar no mesmo dia da 
anunciando a reportagem e a chegada nos próximos dias dessa edição na cidade: Ritual Secreto do Candomblé. Iniciação de Filhas-de-santos na Bahia. Hoje em todas as bancas, chegado via aérea, o novo número da Revista $\mathrm{O}$ CRUZEIRO.

Tal chamada repetiu-se também no jornal Diário de Notícias, pertencente aos Diários Associados, com box anunciando a chegada da revista por cinco dias consecutivos, quatro deles na primeira página, com os dizeres: Hoje em todas as bancas, chegado, por via aérea, o novo número da revista "O Cruzeiro" - com a sensacional reportagem de J osé Medeiros e Arlindo Silva sobre a Iniciação das "Filhas-de-santo", na Bahia - em todas as bancas ao preço comum de quatro cruzeiros. No dia 14 de setembro de 1951, um dia antes da data de capa da revista, o jornal publicou uma das fotografias da reportagem, criando uma expectativa ainda mais tensa sobre o conteúdo da reportagem. A fotografia publicada na contra-capa do jornal mostra uma cena muito forte a um olhar leigo: o sacrifício de um animal na cabeça de uma iaô. A chamada do box em destaque é agressivamente apelativa: O Deus tem sede de sangue, e segue uma parte do texto de Arlindo Silva contextualizando a imagem, trecho literal da longa descrição publicada na revista. Pela primeira vez um jornal publicava uma fotografia de uma iniciação no Candomblé, o que demonstra o forte impacto da chegada da revista, pois outros dois veículos de comunicação de massa prepararam e acentuaram o conteúdo da reportagem. Reforçando ainda mais a reportagem, naquele mesmo dia, o jornal O Estado da Bahia também publicou em primeira página um box exatamente igual aos publicados pelo Diário de Notícias. Assim, todos os principais jornais de Salvador anunciaram a chegada da revista para que nenhum leitor passasse despercebido e incólume à reportagem publicada em O Cruzeiro.

Diz o texto do jornal Diário de Notícias do dia 14 de setembro de 1951, acompanhado da fotografia de sacrifício de animais retratado por J osé Medeiros com o título apelativo envolvendo divindades africanas e sua sede de sangue:

“Esta fotografia é uma das muitas que ilustram, de maneira sensacional e inédita, a reportagem que traz o último número, de O Cruzeiro, já a venda nesta capital. Refere-se as cerimônias da iniciação da filhas-de-santo em toda a sua crueza espetacular e primitiva. Em resumo, trata-se de um autêntico e audacioso 'furo' jornalístico.

O repórter-fotográfico J osé Medeiros e o repórter Arlindo

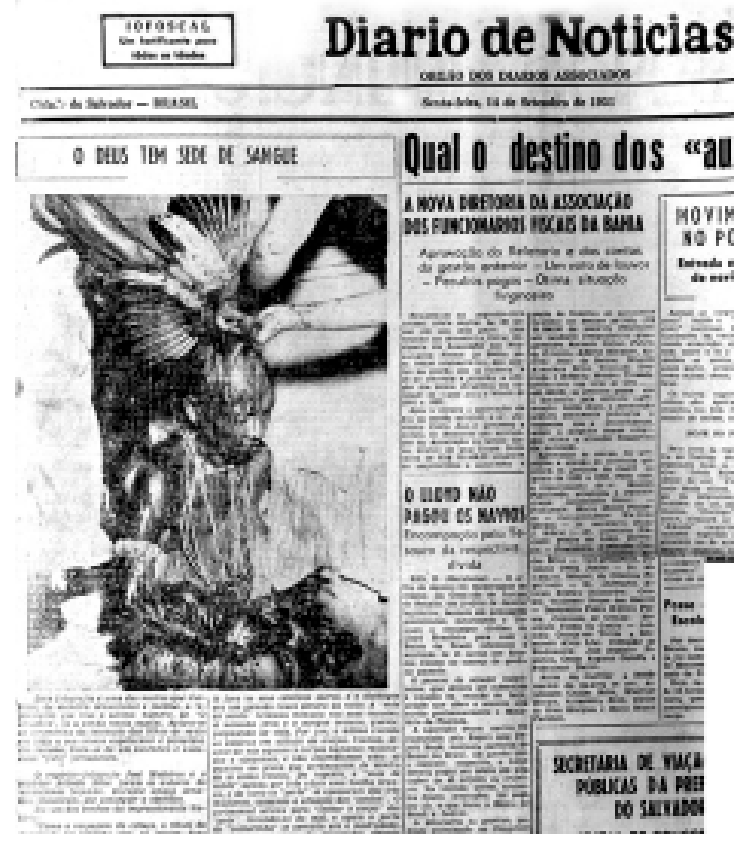

Diário de Notícias, 14.09.1951 
Fernando de Tacca

Silva foram os autores da sensacional façanha. Durante longas semanas, insistiram, até conseguir o objetivo. Eis um dos trechos da impressionante história:

'Como a raspagem da cabeça, o ritual de flagelação foi repetido com as outras duas 'iaôs', sempre na cadeira. Durante mais de uma hora, assistimos a esse dilacerar de carnes ali na 'camarinha'. A navalha não parava. $O$ cheiro de sangue se misturava com o cheiro de suor, as 'filhas-de-santo' entoavam lá fora os seus cânticos sacros, e o atabaque era um gemido rouco dentro da noite. A 'mãe-de-santo' revelava minúcia em suas incisões. A navalha feria e o sangue brotava, quente, palpitando de vida. Por fim, a última incisão foi feita, e as três iaôs se prostaram sobre as esteiras em atitude de oração. Víamos, diante de nós aqueles 3 corpos humanos retalhados e ofegantes, e não entendíamos uma só palavra da prece que arrancavam de dentro de si como roncos. De repente, a 'mãe-de-santo' agitou por três vezes uma toalha branca, e de novo os 'erês' se apossaram das três mulheres, cessando a atuação dos 'santos'. O cerimonial servira para 'fechar o corpo' das 'iaôs', livrando-as do mal, e agora a porta da 'camarinha' se cerraria até a madrugada, quando a cerimônia da 'iniciação' deveria continuar. Em silêncio, deixamos o recinto e companhia da 'mãe-de-santo' e da 'mãe-pequena'. Lá fora, o atabaque já não soava. Era mais de meia-noite."

A importância e o impacto da reportagem da revista O Cruzeiro no meio religioso do Candomblé baiano pode ser compreendido também pelo anúncio que a Federação Baiana de Cultos Afro-brasileiros fez publicar no dia 22 de novembro de 1951, no jornal A Tarde, quase dois meses depois, confirmando uma temporalidade expressiva desse impacto:

"A Federação Bahiana de Culto Afro-Brasileiro tem a grata satisfação de convidar todos os terreiros, os simpatizantes do culto, a imprensa e o povo, em geral, para assistirem à assembléia geral extraordinária, a realizar-se no Domingo, 25 do corrente, às 14:00 horas, $1^{\circ}$ andar, defronte à entrada do Cinema Liceu, a fim de especialmente julgar conveniente as publicações que foram feitas nas revistas 'Paris Match' e 'O Cruzeiro', a respeito do culto africano na Bahia".

\section{PARIS MATCH}

Surpreendentemente, pela primeira vez, desde minha conversa com J osé Medeiros em 1988, quando ele citou que a motivação para a reportagem surgiu após ter visto uma publicação estrangeira sobre candomblé, pude encontrar um elo perdido das informações na Paris Match. Imediatamente, consegui um exemplar ainda em estoque nos arquivos da Paris Match, datada de 12 de maio de 1951, que mostrava uma reportagem de Henri-Georges Clozout na Bahia. A reportagem intitulada Les Possédées de Bahia (As Possuídas da Bahia), tornou-se então o encontro com a motivação fotográfica responsável pela ida de J osé Medeiros para a Bahia, e do empenho desafiador em relação à uma importante publicação estrangeira. A publicação na qual a Federação Baiana de Cultos Afro- 
animada pelos jornais baianos sobre a documentação e publicação de imagens de candomblé. Recortes de jornais encontrados nos arquivos de Pierre Verger mostram que essa acirrada discussão pública deu-se também em torno da Paris Match, e demonstra principalmente $o$ fato de que $o$ famoso fotógrafo e etnólogo estava muito bem informado do que acontecia, apesar de manter-se em silêncio público sobre os acontecimentos.

Roger Bastide será um dos intelectuais que se posicionará na mídia brasileira contra a reportagem da Paris Match e contra Clouzot,

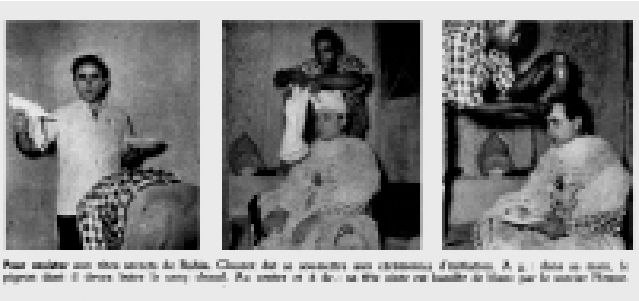

Henri-Gearyes Clouzet rapporte de Brénil un estraerdinaire decumrnt ethoognaphique IDS PUASEEDECLS IDE BIIIIII

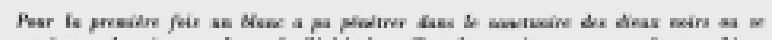

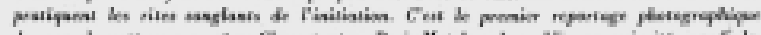

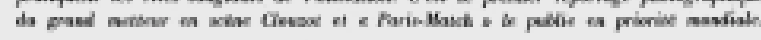

Paris Match, 12.05.1951 num primeiro momento; mas irá fazer a redenção do cineasta francês ao comentar o livro Le Cheval de Dieux, na sua obra O Candomblé da Bahia - Rito Nagô, de 1958. Encontramos também três artigos de Bastide publicados na Revista Anhembi: o primeiro critica acirradamente a reportagem da revista francesa como contribuição etnográfica, acentuando sua carga sensacionalista e preconceituosa; o segundo comenta o livro de Clouzot e suas incoerências e contribuições, fazendo uma espécie de redenção de Clouzot; e o terceiro, não citado no compêndio de sua obra, faz uma análise fria, cautelosa e ambígua da reportagem da revista O Cruzeiro. No terceiro artigo, um pequeno texto intitulado Uma reportagem Infeliz, publicado em dezembro de 1951, Bastide faz uma crítica ao sensacionalismo da reportagem de O Cruzeiro, desclassificando-a como etnografia. Entretanto, sem citá-lo na bibliografia de O Candomblé da Bahia, irá justamente utilizar uma passagem do texto da reportagem como exemplo de uma etnografia importante sobre "possessão de ere".

Para Bastide, a reportagem de $O$ Cruzeiro não pode ser considerada etnografia, mesmo que ele identifique uma "simpatia humana" no texto de Arlindo Silva, o que coloca o artigo em posição superior ao livro de Clouzot. Para Bastide não se trata de um texto de especialista, "pois contém contra-sensos dos mais grosseiros" e, desse ponto de vista, é inferior ao livro de Clouzot. Entretanto, o texto de Arlindo Silva considerado como mero texto jornalístico, longe dos rigores científicos da boa descrição etnográfica, aparece com uma fonte importante em seu livro O Candomblé da Bahia- Rito Nagô. Na análise do estado de erê, Bastide lança mão da descrição de Arlindo Silva: 
“Qual a peculiaridade desse estado, e que nova contribuição pode trazer à nossa pesquisa sobre a filosofia africana? É preciso, naturalmente, antes de responder à segunda pergunta, dar uma descrição do estado de erê; para isso resumimos um artigo pouco conhecido de Arlindo Silva" (Bastide 2001: 193).

Segue uma longa descrição recortada do texto da reportagem ingênua e mal vista por ele no próprio artigo publicado anteriormente em 1951: “Ora, a reportagem de 'O Cruzeiro' não entra no quadro da etnografia”, como ele mesmo acentuou.

Vamos encontrar uma saída metodológica para tal em uma nota no próprio livro. Na nota aparecem citados Clouzot e Medeiros. Em Clouzot, a nota remete-se à numeração do livro e para Medeiros uma reportagem com o título A Purificação pelo Sangue, com data de 15 de agosto de 1951. Tal reportagem de Medeiros não foi encontrada. $\mathrm{Na}$ verdade, inexiste uma revista $\mathrm{O}$ Cruzeiro com essa data e com esse título. Também pesquisamos a revista $\mathrm{A}$ Cigarra e não encontramos tal reportagem. O texto diz:

"As duas reportagens, efetuadas por pessoas que assistiram a cerimônias proibidas, que não podem ser vistas nem fotografadas, são interessantes como documentos vivos. Mas infelizmente nada trazem de novo ao que já conhecíamos por informações orais. Mesmo a abertura do orifício no crânio, de que Clouzot não fala, mas a respeito da qual Medeiros insiste, como se fosse algo inédito, já era conhecida" (Bastide 2001:271, grifo nosso).

Encontramos então uma justificativa para o uso da descrição de erê de Arlindo Silva, a reportagem seria, então, um "documento vivo".

Bastide pergunta se as censuras que foram feitas a Clouzot perderiam sua razão perante a reportagem de $O$ Cruzeiro, e indica um caminho para a imagem do Brasil feita para o olhar estrangeiro, caso da Paris Match, e por outro lado, a circulação de imagens internas que podem prejudicar os fiéis do candomblé. Faz aqui voz com a Federação dos Cultos Afro-Brasileiros, que denunciou Mãe Riso da Plataforma para a polícia e criou uma hostilidade com características agressivas e violentas contra ela em Salvador. Vê também prejuízos sobre o uso das imagens fora do próprio contexto jornalistico por "inimigos do candomblé" que poderiam usá-las como ferramenta para fechamento dos terreiros, ou seja, as imagens alimentariam uma hostilidade já existente contra a religião. Bastide extrapola: "Elas podem até tornar-se uma arma de guerra civil" (Bastide 1951c: 564).

Novamente, quase ao final desse artigo, Bastide inocenta os produtores de imagens e joga a culpa de uma forma maniqueísta na mãe-de-santo que se deixou fotografar: "Faço questão de proclamar que os fotógrafos não são os principais responsáveis. A responsabilidade maior cabe ao candomblé que permitiu que se tirassem fotografias dessa ordem". Não sei se essa afirmação livrou Medeiros de seus temores ao voltar à Bahia e ter de enfrentar os ebós que teriam sido preparados para ele. Entretanto, o sociólogo francês atenua a responsabilidade dos candomblés ao ressaltar o fato de a maioria dos candomblés serem de classes pobres da sociedade e necessitarem de dinheiro para sua cerimônias sempre muito custosas: 
“Eis o drama. É a conseqüência da multiplicação abusiva dos candomblés. Os antigos e os mais tradicionais são ricos, podem defender os seus segredos; mas os mais novos que, por enquanto, têm apenas uma clientela restrita são mais permeáveis às influências de desagragação moral, por falta de segurança econômica" (Bastide 1951c: 564)

O que ele quis dizer com "multiplicação abusiva"? Nem parece que o grande sociólogo desconhece a dinâmica própria do candomblé na qual não existe uma hierarquia burocrática que permite abrir, fechar ou restringir cerimônias, e essa riqueza cultural prolifera por toda periferia de Salvador, longe das casas tradicionais. Coloca-se nesse ponto de vista uma dicotomia muito utilizada entre os detentores do saber dos terreiros mais antigos e os terreiros populares, sem tradição. Talvez até mesmo entre cidade alta e cidade baixa! Redes de candomblé que não se cruzam.

Ainda no final desse mesmo artigo, Bastide vê uma crise moral se abatendo sobre o candomblé em virtude das duas reportagens publicadas pela Paris Match e pelo O Cruzeiro. Essa crise moral, da qual as reportagens seriam testemunhas, segundo ele, abate-se também sobre as casas tradicionais? Afinal, não foram elas que permitiram as imagens. Então, por que distinguir a fonte do saber? E finaliza, dizendo literalmente que "A única instituição com autoridade para resolvê-la é a Federação das Seitas Afro-Brasileiras". A Federação tomou as providências no caso de Mãe Riso da Plataforma, fez dela um caso de polícia! Mas lembrando, Riso consultou seu orixá, Oxóssi, e foi por ele autorizada a deixar-se fotografar. Como bem sabia Roger Bastide, no candomblé os pais-de-santo e as mães-de-santo têm acesso direto às divindades e não precisam para isso de autorização de uma instituição burocrática como a Federação, e nem mesmo de seus pares; o canal místico é único e singular, o que torna ainda mais fascinante esse mundo religioso. Em depoimento recente, a irmã de Riso, disse-nos que ela consultou seu santo, Oxóssi, e o santo autorizou-a deixar Medeiros fotografar a iniciação. Quem então autoriza as fotografias?

Seis anos depois da publicação da reportagem de 1951, a mesma editora da revista O Cruzeiro publicou o livro Candomblé, em 1957, com todas as fotografias veiculadas na revista, com um acréscimo considerável de mais algumas escolhidas por Medeiros, totalizando 60 imagens, 22 fotografias a mais. A nova forma de publicação colocou as mesmas imagens em outro formato e em outra valorização. Se na revista o artifício jornalístico era o sensacionalismo para atingir um formato popular direto e ofensivo à religião, já a partir do próprio título, no livro, as imagens passaram a ser um material etnográfico precioso e único.

O material fotográfico coletado por J osé Medeiros transforma-se em conteúdo. De uma primeira publicação marcada por um fotojornalismo sensacionalista transforma-se em um documento etnográfico na apresentação gráfica e nas marcações das legendas no formato livro. Na primeira versão temos uma profanação do espaço do sagrado, permitido somente para os iniciados, ao torná-lo visível ao olhar, um olhar leigo massificado pela 
Fernando de Tacca

importância da revista O Cruzeiro na opinião pública da época. Na segunda versão temos as mesmas imagens, mas sem o tratamento sensacionalista, com uma abordagem que transparece uma aparente neutralidade na explicitação visual do ritual, transformando-as em documento etnográfico ou "científico", coroando-as com uma nova aura para o sagrado profanado. Transparece assim um foco de tensão e revolta de um sentimento nacional posterior à publicação da revista Paris Match criando um campo propício para a revista O Cruzeiro dar sua resposta. O deslocamento contextual encontra a gênese da fotografia como realidades múltiplas, permitindo, desta forma, significações diferenciadas, sagradas ou profanas, conformando o que expomos conceitualmente como Fricção Ritualística.

Os formatos de apresentação de material etnográfico nos meios de comunicação de massas e suas decorrentes conseqüências com a invasão do olhar leigo, voyeur e massificado, muitas vezes preconceituoso e induzido pela mídia em relação às cerimônias e rituais tradicionais de culturas locais não globalizadas, produz significações descontextualizadas muitas vezes pejorativas e elevadas ao campo do exótico e da humilhação. Entretanto, as mesmas imagens de cunho sensacionalista veiculadas por mídias populares, quando descoladas do contexto jornalístico, reencontraram seu referente vivificado no seu intrínseco valor etnográfico, com todas as conseqüências desastrosas que acarretaram.

\section{A FRICÇÃO RITUALÍSTICA}

Os processos sociais nomeados como rituais de passagem (Van Gennep 1978, Turner 1974, Leach 1978) caracterizam uma zona marginal na qual os iniciados em uma religião e inúmeras outras situações sociais, como acentua Van Gennep no próprio subtítulo de seu trabalho, ficam isolados da marcação linear temporal da sociedade vivendo um tempo mágico e um estado social diferenciado. Os ritos de passagem são marcados por cerimônias de separação (preliminares) e de agregação (pós-liminares) que criam no seu interstício, muitas vezes de longa duração, um estado de liminaridade acentuado principalmente nos casos de ritos de iniciação. As características da liminaridade às quais o neófito está sujeito são: submissão, silêncio, ausência de sexualidade e anonímia. São entidades em transição, em passagem, não tendo lugar nem posição, pois todos os atributos da ordem social são suspensos e as categorias e grupos sociais dissolvem-se na morte social da liminaridade.

Assim Turner refere-se à esse estado do evento social nos ritos de passagem: 
“O neófito na liminaridade deve ser uma tábula rasa, uma lousa em branco, na qual se inscreve o conhecimento e a sabedoria do grupo, nos aspectos pertinentes ao novo "status". Os ordálios e humilhações, com freqüência de caráter grosseiramente fisiológico, a que os neófitos são submetidos, representam em parte, a têmpera da essência deles, a fim de prepará-los para enfrentar as novas responsabilidades e refreá-los de antemão, para não abusarem de seus novos privilégios. É preciso mostrar-lhes que, por si mesmos, são barro ou pó, simples matéria, cuja forma lhes é impressa pela sociedade" (1974:127).

Da mesma forma, utilizando os mesmos procedimentos conceituais, a fotografia pode ser considerada como um ritual de passagem (Tomas 1982, 1983 e 1988). Tomas parte da estrutura proposta por esses autores para encontrar similitudes no processo entre o ato fotográfico em si, no momento único de sua indicialidade, e seus procedimentos técnicos no processamento da imagem como um ritual de passagem. De forma sintética, para Tomas, o rito de separação na cerimônia fotográfica é desprendimento da materialidade e os processos óticos de inversão para um suporte bidimensional. A negatividade e a ausência de luz significaria o momento da liminaridade, a imagem latente não processada quimicamente e seu processo de formação de uma imagem negativa da realidade. A agregação é a criação da condição de positividade da imagem e sua inserção no campo social. A morte simbólica por intermédio da redução ótica e na espacialidade do suporte bidimensional, transforma-se em "ponte de permanência" de uma cena ou de uma pessoa, ou seja, a ligação entre o fotógrafo e o espectador da imagem criando um "eterno presente". Diz Tomas:

“O ritual fotográfico concedeu presença na ausência do objeto fotográfico; processou a imagem de luz, e a transpôs quimicamente. O objeto é agora estável e permanente como imagem na sociedade. O ritual fotográfico funciona para marcar simbolicamente a morte do objeto pela sua transformação óptica e dimensional. Ademais, ele congela o objeto "não-estruturado" durante um período de isolamento ritual e sagrado e, finalmente, marca a reintrodução ou reencarnação do objeto na sociedade por meio de sua "reestrutruturação", na forma de um novo estado fotográfico da atemporalidade e da ilimitabilidade social e simbólica" (1982:09)

A similitude dos processos entre um ritual de passagem na sua liminaridade com a imagem técnica da fotografia, também marcado por um processo ritualizado que cria campos marginais com todas as características dos ritos de passagem, transfere o rompimento da linearidade do tempo social, e entenda-se aqui o espaço do sagrado nesses rituais, para outra categoria liminar, agora no campo das imagens técnicas. A superposição das liminaridades justapõe a proibição da visão nas reclusões dos iniciados e na imagem latente da película. A existência de dois campos marginais, ou liminares, cria uma fricção ritualística entre o sagrado contextualizado na cosmologia religiosa e os mecanismos ideológicos no processamento da imagem técnica, ou seja, a metáfora de Turner para a modelagem do barro pela matéria nuclear, a transformação do pó, aplica-se à modelagem da luz pelos grãos de prata, uma construção imagética social que Ihes dá forma existencial além da primeira realidade. A morte social 
Fernando de Tacca

encontra aqui similitude na morte da primeira realidade, já que prisioneira do recorte temporal e espacial do campo fotográfico, ressurge na agregação como um conceito, uma imagem conceito (Tacca 2001).

Ao trazer ao olhar leigo o campo elegido da magia ou do contato primordial com as divindades, o campo marginal da imagem fotográfica assume e superpõe sua liminaridade ao campo religioso, uma nova magia estabelece-se alterando o conteúdo original do sagrado, nas palavras de Flusser:

“A nova magia não visa modificar o mundo lá fora, como faz a pré-história, mas os nossos conceitos em relação ao mundo. É magia de segunda ordem: feitiço abstrato. Tal diferença pode ser formulada da seguinte maneira: a magia pré-histórica ritualiza determinados modelos, mitos. A magia atual ritualiza outro tipo de modelo: programas. Mito não é elaborado no interior da transmissão, já que é elaborado por um "deus". Programa é modelo elaborado no interior mesmo da transmissão, por "funcionários". A nova magia é ritualização de programas, visando programar seus receptores para um comportamento mágico programático."(1985:22)

Guardado na escuridão para preservar seu campo liminar, a imagem latente não pode causar danos para o sagrado religioso, mantém-se invisível na escuridão do sagrado fotográfico; temos então o sagrado superposto. Entretanto, ao dar-se a ver, e de forma pública, rompe-se a estrutura própria do segundo campo liminar, expondo a liminaridade inicial, mas ainda somente para os olhos individualizados do fotógrafo ou de seu laboratorista, ou mesmo de algumas pessoas da redação. A publicação da imagens decreta a profanação do sagrado. Aqui aproximamos do que Van Gennep chamou de "rotação do sagrado". A rotatividade do sagrado, ou como diz Da Mata (1978), a "relatividade do sagrado". Perde-se a aura original do fechamento social da reclusão após se tornar imagem massificada, mas cria-se no deslocamento original do profano um nova ordem sagrada, a ordem mágica e programática das imagens técnicas (Flusser 1985). O sagrado desloca-se de seu sítio apreendido na câmara escura, guardiã dos segredos originais quando ainda latente, para concretizar-se em imagens visíveis. No relativismo do campo religioso do Candomblé cristaliza-se a profanação; na existência do documento etnográfico único, uma nova ordenação do sagrado existindo no campo imagético; o fotógrafo torna-se feiticeiro, ou melhor dizendo, sacerdote de uma ordem superior da sociedade tecnológica, um embate de duas magias. O fotógrafo/feiticeiro extrapola a "lógica da falácia do bruxo" (Leach 1978: 37-40), pois ao invés de cometer o "erro" de transformar um símbolo metafórico em signo metonímico estará epistemologicamente sempre dentro do campo da indicialidade, ou a existência por contigüidade física (Dubois 1994: 94); ou ainda, no processo de construção da significação do signo fotográfico implicadas em superposição entre significante e referente (Barthes 1980:18), mesmo que o operador seja simplesmente um mero "funcionário do programa” (Flusser 1985:22).

Aprofundando a liminaridade fotográfica, lembramos o que dissemos antes, ou seja, a técnica fotográfica manipulada por Medeiros propiciou uma exposição longa, com tempo indefinido na posição B, que atua no tempo 
extenso do obturador aberto no toque do dedo e na velocidade intensa e rápida do flash para guardar a imagem latente em película e levá-la em liminaridade para outros espaços, o laboratório, e depois a visibilidade da publicação das imagens nos meios de comunicação.

O deslocamento do profano no roteiro revista - livro permite voltar à Van Gennep e o "deslocamento dos círculos mágicos" que conforme uma posição ou outra na sociedade muda-se o lugar do indivíduo ou de seu status:

“Quem passa, no curso da vida, por estas alternativas encontra-se no momento dado, pelo próprio jogo das concepções e das classificações, girando sobre si mesmos e olhando para o sagrado em lugar de estar voltado para o profano, ou inversamente" (Van Gennep 1977:32).

O referente aderido à imagem fotográfica perde sua carga mítica original descontextualizando o evento religioso, para transformar-se em outra magia, uma magia contemporânea que não se propõe a modificar o mundo e sim nossos conceitos sobre o mundo (Flusser 1985:22). Ou o que esse autor chama de magia de segunda ordem, e com essa carga intencional, o sensacionalismo urge para os olhares maniqueístas da cultura na categorização de um primitivismo religioso visto pejorativamente pelos valores estabelecidos do "bem". Dessa forma, o fotógrafo substitui com eficácia o feiticeiro/xamã/pai-de-santo criando uma nova ordem imagética e programática na sociedade de consumo de imagens enquanto mercadorias simbólicas.

Fernando de Tacca éfotógrafo e professor do Departamento de M ultimeiosdaU nicamp, atual coordenador do Prêmio Pierre Verger de Vídeo e Fotografia da Associação Brasileira de Antropologiae editor da revista eletrônica Studium: http://www.studium.iar.unicamp.br 
Fernando de Tacca

\section{NOTAS}

1 Comunicação apresentada no Fórum de Pesquisa no 24, "Antropologia Visual e Imagem no Mercosul", da IV Reunião de Antropologia do Mercosul.

2 Pesquisa realizada através da Bolsa Vitae de Artes/Fotografia 2002.

3 Termo que designa as pessoas que estão em processo de iniciação no Candomblé.

4 Depoimento no catálogo da exposição "j osé Medeiros - 50 Anos de Fotografia", Funarte, RJ , 1986, p.15.

5 Dispositivo que permite sensibilizar a película por quanto tempo desejar o fotógrafo, enquanto estiver apertando o botão disparador o filme está sendo exposto à luz. 


\section{REFERÊNCIAS BIBLIOGRÁFICAS}

Accioly Netto, Antonio. 1998. O Império do Papel - Os Bastidores de O Cruzeiro. Porto Alegre: Sulina.

Corrêa, Thomaz Souto. 2000. A Revista no Brasil. 2000. São Paulo: Abril

Barthes, Roland. 1980. A Câmara Clara. Lisboa: Edições 70.

Bastide, Roger. 2001. O Candomblé da Bahia - Rito Nagô. São Paulo: Companhia das Letras. 1951a. "A etnologia e o sensacionalismo ignorante". Revista Anhembi 9 (III). 1951b. "O caso Clouzot e Le Cheval de Dieux". Revista Anhembi 10 (IV). 1951c. “Uma reportagem infeliz". Revista Anhembi 12 (IV).

Carvalho, Luiz Maklouf. 2001. Cobras Criadas. São Paulo: Senac.

Dubois, Philippe. 1994. O Ato Fotográfico e outros Ensaios. Campinas: Papirus.

Da Matta, Roberto. 1978. "Apresentação”. In A. Van Gennep. Os ritos de passagem, Petrópolis: Vozes.

Eliade, Mircea. 2001. O Sagrado e o Profano. São Paulo: Martins Fontes.

Flusser, Vilém. 1985. Filosofia da Caixa Preta - Ensaios para uma futura filosofia da fotografia. São Paulo: Hucitec.

Leach, Edmund. 1978. Cultura e Comunicação - A lógica pela qual os símbolos estão ligados - Uma introdução ao uso da análise estruturalista em Antropologia Social. Rio de J aneiro: Zahar.

Medeiros, J osé. 1957. Candomblé, Rio de J aneiro: O Cruzeiro.

Peregrino, Nadja \& Magalhães, Angela. 1986. J osé Medeiros. Rio de J aneiro: Funarte.

Peregrino, Nadja. 1991. Cruzeiro - A Revolução da Fotorreportagem. Rio de J aneiro: Dazibao

Parks, Gordon. 1978. Flávio. New York: Norton.

Tacca, Fernando de. 1999. "O Feitiço Abstrato". Cadernos da Pós-Graduação, Instituto de Artes (2).

Tomas, David. 1983. "The ritual of photography". Semiotica 40 (1/2).

1982. "A mechanism for meaning - A ritual and the photographic process", Semiotica 46(1). 1988. "Toward and anthropology of sight - Ritual performance and the photographic process". Semiotica 68(3/4).

Turner, Victor W. 1974. O Processo Ritual. Petrópolis: Vozes.

Van Gennep, Arnold. 1978. Ritos de Passagem. Petrópolis: Editora Vozes. 
Fernando de Tacca

\section{RESUMO}

Em 1951, a revista O Cruzeiro publicou uma reportagem sobre um ritual de iniciação no Candomblé, na Bahia, com o seguinte título "As Noivas dos Deuses Sanguinários", com 42 fotografias de J osé Medeiros. Seis anos depois, a mesma editora publicou um livro, chamado de "Candomblé", com mais 22 fotografias inéditas. A nova forma de publicação colocou as mesmas imagens em outro formato e em outra valorização imagética. Pretendemos nessa comunicação discutir o deslocamento dos significados sociais entre o sensacionalismo e a documentação etnográfica. A partir de um estudo de caso, pretendemos discutir os formatos de apresentação de material etnográfico nos meios de comunicação de massas e suas decorrentes conseqüências com a invasão de um olhar leigo "voyerista" e, muitas vezes preconceituoso, induzido pela mídia em relação às cerimônias e rituais tradicionais de culturas locais não globalizadas.

\section{ABSTRACT}

In 1951, O Cruzeiro Magazine published an article about an initiation ritual of candomble in Bahia, with the title "The Brides of the Sanguinary Gods", with 42 photographs taken by J osé Medeiros. According to Medeiros, the publication brought a lot of controversy to the Candomblé world in Bahia. Six years later, the same publisher for O Cruzeiro published a book, entitled "Candomblé", with all the pictures from the article plus 22 others. This paper discusses the presentation of the material related to "traditional" rituals e ceremonies by mass-communication media and the consequences of its often-prejudiced vision of other cultures. 